\title{
Työn ja talouden hallinta laajentaneilla lypsykarjatiloilla
}

\author{
Marja Manninen \\ MTT Taloustutkimus, Luutnantintie 13,00410 Helsinki,marja.manninen@mtt.fi
}

\section{Tiivistelmä}

Tutkimuksen tavoitteena oli selvittää, miten viljelijäperheen sekä palkatun työvoiman tekemän maataloustyön määrä on tilan tuotannon laajennuksen yhteydessä muuttunut ja miten laajennus on vaikuttanut tilan toimintoihin ja kannattavuuteen. Lisäksi tarkasteltiin viljelijöiden jaksamista ja stressikokemuksia sekä laajennusvaiheessa ja sen jälkeen tilalla ilmeneviä ongelmia.

Tutkimusaineistona käytettiin vuoden 2002 kirjanpitotilojen taloudellisia tuloksia sekä kirjanpitotiloille samana vuonna tehtyä kyselyä. Kirjanpitotila-aineistossa oli 156 viljelijäkyselyyn vastannutta lypsykarjatilaa, joiden tiedot olivat tarkastelussa mukana vuosina 1998-2002. Tutkimuksessa asetettujen peltoalan ja lehmämäärän kasvamiseen perustuvien kriteerien avulla aineistosta poimittiin 66 tuotantoaan laajentanutta tilaa. Laajentaneiden ja ei-laajentaneiden tilojen välisiä eroja ja viljelijäperheen jaksamiseen vaikuttaneita tekijöitä tutkittiin käyttämällä ei-parametrisia menetelmiä. Laajentaneiden tilojen ongelmia tarkasteltiin faktori- ja ryhmittelyanalyysilla.

Laajentaneilla tiloilla kokonaistyömäärä oli ei-laajentaneita tiloja suurempi, samoin investointitöitä ja muita maataloustöitä (sisältää mm. johtamistyön) tehtiin näillä tiloilla eniten. Palkatun työvoiman osuus oli laajentaneilla tiloilla tilastollisesti merkitsevästi ei-laajentaneita tiloja suurempi. Vieraan työn määrä oli kuitenkin lisääntynyt kaikilla tiloilla. Laajentaneilla tiloilla kannattavuuskerroin oli vuosina 1998-1999 eilaajentaneita tiloja alhaisempi. Kahtena tarkastelujakson viimeisenä vuotena kannattavuuskerroin oli laajentaneilla tiloilla jo merkitsevästi suurempi kuin ei-laajentaneilla tiloilla.

Laajentaessaan tuotantoa viljelijät uskoivat enemmän tulevaisuuteen kuin ei-laajentaneet viljelijät eivätkä kokeneet yhtä paljon stressiä mahdollisista toimintaympäristön muutoksista. Suhtautuminen elämiseen ja yrittämiseen oli laajentaneiden tilojen viljelijöillä myönteisempää kuin ei-laajentaneiden tilojen viljelijöillä. Mitä suurempi oli tilan kokonaistyömäärä, sitä enemmän stressiä työmäärä aiheutti.

Faktori- ja ryhmittelyanalyysien perusteella lypsykarjatiloista muodostui ryhmiä, joilla laajentamisvaiheen ongelmallisuus vaihteli. Ensimmäisen, suurimman (24 tilaa) ryhmän tiloilla toiminnot oli suunniteltu ja organisoitu toisia huolellisemmin tai laajennusta ei koettu ongelmalliseksi. Toisen ryhmän tiloilla (18 kpl) ei päästy hyödyntämään laajentunutta tuotantokapasiteettia täysimääräisesti heti laajennuksen jälkeen, ja ongelmina olivat tuotannon epätasapaino ja töiden hallinta. Kolmannessa ryhmässä, johon kuului vajaa kolmannes tiloista, ongelmia aiheuttivat tilan johtaminen ja rahoituksen järjestäminen. Tilan laajennukseen liittyvillä ongelmilla ei kuitenkaan havaittu olevan yhteyttä tähän tutkimukseen valittuihin tilakokoa, työnmenekkiä ja taloudellista tulosta kuvaaviin taustamuuttujiin.

Asiasanat: lypsykarjatila, laajennus, työnmenekki, johtaminen, stressi 


\section{Johdanto}

Maataloudessa on jo pidemmän aikaa ollut käynnissä voimakas rakennemuutos. Maatilojen keskikoko on kasvanut nopeasti, ja monilla pienillä tiloilla taloudelliset toimintaedellytykset ovat heikentyneet. Pienten tilojen osuus on vähentynyt voimakkaasti. Rahoitustuki on suunnattu entistä kasvuhakuisempien ja suurempien tilojen viljelijöille.

Maatalouden osuus viljelijöiden kokonaistuloista on alentunut tasaisesti viimeisen kymmenen vuoden aikana (Väre 2000). Osa viljelijöistä onkin joutunut laajentamaan tilansa tuotantoa pelkästään säilyttääkseen aiemman tulotasonsa. Tilakokoa kasvattamalla voidaan alentaa keskimääräisiä yksikkökustannuksia. Samalla voidaan yrityksen mahdollisesti vajaakäytössä olleet resurssit käyttää aiempaa tehokkaammin hyväksi tuotannossa (Kay ja Edwards 1999).

Lypsykarjatilan laajennus sitoo runsaasti pääomaa ja vaatii pitkäjänteistä sekä ammattimaista suunnittelua. Viljelijä joutuu investointien maksajana ja vastuun kantajana tekemään lopulliset päätökset. Laajennuksen yhteydessä on tärkeää huomioida myös työpanoksen riittävyys, sillä päätoimisista maatilayrittäjistä maidontuottajilla on suurin vuotuinen kokonaistyömäärä. Työaikaa kertyy viikossa usein yli 60 tuntia. Sesonkityöt kuten kevätkylvöt, rehunkorjuut, puinnit ja syyskynnöt lisäävät työpäivän pituutta entisestään (Karttunen ja Klemola 2001). Viljelijät saattavat olla monesti jaksamisensa äärirajoilla. Maatilayrittäjien työn määrän hallinta, jaksaminen sekä stressi ovatkin tärkeitä ja ajankohtaisia kysymyksiä.

Tämän tutkimuksen tavoitteena oli selvittää:

1) Miten viljelijäperheen sekä palkatun työvoiman tekemän maataloustyön määrä on laajennuksen yhteydessä muuttunut ja ovatko muutokset vaikuttaneet tilan toimintoihin ja taloudellisiin tuloksiin?

2) Miten laajennus on vaikuttanut viljelijöiden jaksamiseen?

3) Mitä ongelmia tilan toimintojen hallinnassa on ilmennyt sekä laajennusvaiheessa että sen jälkeen?

\section{Aineisto ja menetelmät}

Tutkimusaineistona käytettiin vuoden 2002 kirjanpitotilojen taloudellisia tuloksia sekä kirjanpitotiloille samana vuonna tehtyä kyselyä. Kirjanpitoaineistossa oli 95 lypsykarjatilaa, jotka eivät olleet vastanneet viljelijäkyselyyn. Katoanalyysin perusteella voitiin todeta, että tulosten yleistettävyys oli hyvä, eivätkä vastaamatta jättäneiden tilojen tiedot aiheuttaneet vääristymää tutkimusaineiston tuloksiin.

Viljelijäkyselyyn vastanneiden 156 lypsykarjatilan joukosta poimittiin ne tilat, jotka olivat vuosien 1998-2002 aikana lisänneet lehmämääräänsä yli 20 prosenttia (kuitenkin vähintään 5 lehmää) ja/tai kasvattaneet kokonaispeltoalaa joko ostamalla tai vuokraamalla yli 20 prosenttia (kuitenkin yli 6 hehtaaria). Näillä ehdoilla aineistosta saatiin poimittua 66 tilaa. Laajentaneilla tiloilla oli vuosina 19982002 keskimäärin 25,4 lehmää ja 45,7 hehtaaria peltoa (oma ja vuokrattu pelto yhdessä). Ei-laajentaneilla tilakoko oli merkitsevästi pienempi eli lehmiä oli 17,8 ja peltoa 33,6 hehtaaria. Lehmämäärä oli kasvanut laajentaneilla tiloilla vuosien 1998-2002 välillä keskimäärin 7,2 lehmällä ja ei-laajentaneilla tiloilla vain 0,4 lehmällä. Peltoala oli lisääntynyt keskimäärin 13,7 hehtaarilla laajentaneiden tilojen ryhmässä, kun vastaava luku ei-laajentaneiden tilojen ryhmässä oli 1,4 hehtaaria.

Parametristen testien edellytykset eivät täyttyneet aineiston muuttujilla. Kahden populaation vertailussa on käytetty Mann-Whitneyn U-testiä. Usean otoksen vertailuun sopiva yleistys ManninWhitneyn testistä on Kruskalin-Wallisin yksisuuntainen varianssianalyysi (Ranta ym. 1997). Tutkimuksessa käytettyjen monimuuttujamenetelmien avulla voidaan tiivistää useita muuttujia sisältävän laajan aineiston informaatio selvästi aikaisempaa pienempään määrään muuttujia. Faktorianalyysi on tilastotieteellinen lähestymistapa, jonka avulla voidaan analysoida useiden muuttujien välisiä keskinäisiä suhteita ja selittää näitä muuttujia niiden taustalla olevien yhteisten ulottuvuuksien eli faktoreiden avulla. Ryhmittelyanalyysissa tarkoituksena on paljastaa ryhmien oikea lukumäärä ja luokitella aineiston havainnot näihin ryhmiin (Chatfield ja Collins 1980). 


\section{Tulokset ja tulosten tarkastelu}

Vertailtaessa tuotantoaan laajentaneita ja ei-laajentaneita tiloja taustamuuttujien avulla havaittiin, että laajentaneilla tiloilla maataloustulo oli suurempi sekä lehmiä ja peltoalaa oli merkitsevästi enemmän. Laajentaneilla tiloilla kannattavuuskerroin oli tarkastelujakson alussa alhaisempi, mutta kannattavuus kääntyi kuitenkin nousuun niin, että kahtena tarkastelujakson viimeisenä vuonna kannattavuuskerroin oli laajentaneilla tiloilla jo merkitsevästi suurempi kuin ei-laajentaneilla.

Laajentaneilla tiloilla työn kokonaismäärä oli suurempi, samoin investointitöitä ja muita maataloustöitä (sisältää mm. johtamistöitä) tehtiin enemmän. Maataloustöiden osuus kokonaistöistä oli eilaajentaneita tiloja pienempi. Laajentaneilla tiloilla työn tuottavuus oli merkitsevästi suurempi eli työtä tehtiin eläinyksikköä kohden laskettuna vähemmän. Laajentaneilla tiloilla ei kuitenkaan tehty tilastollisesti merkitsevästi enempää metsä- ja puutarhatalouden töitä tai muun yritystoiminnan töitä.

Sekä oman että vieraan työvoiman tekemän maataloustyön määrät olivat laajentaneilla tiloilla suuremmat kuin ei-laajentaneilla tiloilla. Kuitenkin vain vieraan työpanoksen ero oli tilastollisesti merkitsevä (taulukko 1). Laajentaneilla tiloilla oli käytössä selkeästi enemmän vierasta työpanosta työtunneissa mitattuna, mutta viljelijäperheen oma työpanos ei eronnut yhtä selkeästi.

Taulukko 1. Maataloustyön käytön keskiluvut ja ryhmien eron tilastollinen merkitsevyys.

\begin{tabular}{|c|c|c|c|c|c|c|c|}
\hline & \multicolumn{3}{|c|}{ Laajentaneet tilat } & \multicolumn{3}{|c|}{ Ei-laajentaneet tilat } & \multirow[t]{2}{*}{$\mathrm{p}$-arvo } \\
\hline & minimi & maksimi & keskiarvo & minimi & maksimi & keskiarvo & \\
\hline $\begin{array}{l}\text { Oma maataloustyö, } \\
\text { h/tila } \\
\text { Vieras }\end{array}$ & 1852 & 7513 & 4856 & 2273 & 7748 & 4522 & 0 \\
\hline maataloustyö, h/tila & 0 & 2673 & 423 & 0 & 2326 & 269 & $*$ \\
\hline
\end{tabular}

Tilat ryhmiteltiin viljelijäperheen oman ja vieraan työvoiman tekemän maataloustyön määrän (h/tila) perusteella muodostettuihin luokkiin viiden vuoden viiden vuoden tarkastelujaksolla. Työmäärä vaihteli tiloilla suuresti. Ei-laajentaneilla tiloilla pienimpään oman maataloustyön luokkaan kuuluvien tilojen osuus kasvoi huomattavasti verrattuna laajentaneisiin tiloihin. Myös kahteen suurimman oman työpanoksen luokkiin kuuluvien osuus oli laskussa ei-laajentaneilla tiloilla. Myös laajentaneilla tiloilla suuntaus oli se, että tilamäärä pienimmässä oman maataloustyön luokassa oli kasvussa eli oman työn määrä oli osalla tiloista vähenemässä.

Osalla tiloista ei käytetty lainkaan vierasta työpanosta. Tähän ryhmään kuului vuodesta riippuen noin 35-46 prosenttia laajentaneista tiloista ja noin 48-64 prosenttia ei-laajentaneista tiloista. Vain oman työpanoksen varassa toimivia tiloja oli näin ollen enemmän ei-laajentaneilla tiloilla. Laajentaneiden tilojen ryhmässä vain oman työpanoksen varassa toimivien tilojen osuus laski huomattavasti viiden vuoden aikana. Tämä kertoo vieraan työpanoksen kasvun tarpeesta tiloilla. Tuloksia tarkasteltaessa on huomioitava, että kirjanpitotilojen työmäärät eivät sisällä tilalle ostettua koneurakointityötä.

Vertailtaessa laajentaneiden ja ei-laajentaneiden tilojen viljelijöiden stressikokemuksia voitiin todeta, että laajentaneiden tilojen viljelijät kokivat maataloustöistä aiheutuvaa stressiä hieman useammin. Erot eivät olleet tilastollisesti merkitseviä. Investoidessaan ja laajentaessaan tuotantoa viljelijät kuitenkin uskoivat enemmän tulevaisuuteen eivätkä kokeneet yhtä paljon stressiä mahdollisista toimintaympäristön muutoksista. Suhtautuminen elämiseen ja yrittämiseen oli laajentavien tilojen viljelijöillä positiivisempaa.

Puolison stressaantuminen oli yleisempää miesten vastauksissa verrattuna naisiin. Tästä voidaan päätellä, että naiset mahdollisesti stressaantuivat miehiä helpommin. Myös iällä oli tilastollisesti merkitsevää vaikutusta. Puoliso oli useammin stressaantunut vanhemman ikäluokan vastauksissa. Vastaajan omia stressikokemuksia käsittelevissä vastauksissa sukupuoli ja ikäluokka eivät kuitenkaan eronneet merkitsevästi. Niillä, joista eläminen tuntui paremmalta vielä 90 -luvun alkupuolella, oli hieman muita heikompi kannattavuuskerroin ja pienempi maataloustulo. Iällä oli merkitsevää vaikutusta, sillä vanhemmat viljelijät eivät olleet yhtä tyytyväisiä nykytilaan nuorempiin viljelijöihin verrattuna. Tiloilla, joilla työmäärät olivat suuria, katsottiin muita useammin stressin ja henkisten paineiden kuuluvan osana 
yrittämiseen.

Maataloustuotannon muutokset tilalla ja elinkeinon epävarmuus huolestuttivat eniten niitä, joilla oli pieni lehmämäärä. Taloudellinen tilanne stressin taustalla vaikutti erityisesti heikosti kannattavilla tiloilla. Niillä, jotka kokivat stressiä tilan työmäärästä, ei kuitenkaan ollut merkitsevästi suuremmat oman ja vieraan maataloustyön määrät. Merkitsevä ero ilmeni tilan kokonaistyömäärää tutkittaessa. Mitä suurempi oli tilan kokonaistyömäärä, sitä enemmän stressiä työmäärä aiheutti. Työmäärän hallitseminen oli ongelmallista myös niillä tiloilla, joilla oli enemmän lehmiä ja peltoalaa. Näillä tiloilla oli myös pienempi maataloustulo ja kannattavuuskerroin niihin tiloihin verrattuna, jotka eivät olleet kokeneet stressiä työmäärästä.

Faktori- ja ryhmittelyanalyysien perusteella voitiin todeta, että lypsykarjatiloilta erottui ryhmiä, joilla laajentamisvaiheen ongelmallisuus vaihteli. Ensimmäisen, suurimman ryhmän $(24 \mathrm{kpl})$ tiloilla toiminnot oli suunniteltu ja organisoitu toisia huolellisemmin tai toimintojen hallintaa ei koettu ongelmalliseksi. Toisen ryhmän tiloilla $(18 \mathrm{kpl})$ ei päästy hyödyntämään laajentunutta tuotantokapasiteettia täysimääräisesti heti laajennuksen jälkeen. Tällaiset tuotannon epätasapainotilat aiheuttavat yleensä myös taloudellisia tappioita. Monesti laajennuksen yhteydessä saatetaan siirtyä nykyistä kehittyneemmän tuotantoteknologian käyttöön, mikä saattaa muuttaa työprosesseja ja maataloustyön luonnetta. Uusi tuotantoteknologia saattaa lisätä alussa viljelijän työmäärää sopeutumisvaikeuksien vuoksi. Kolmannella ryhmällä, johon kuului vajaa kolmannes tiloista, vaikeuksia aiheuttivat johtamisen ja rahoituksen ongelmat. Laajentaneiden tilojen ongelmilla ei havaittu olevan yhteyttä tähän tutkimukseen valittuihin taustamuuttujiin.

\section{Johtopäätökset}

Tutkimuksen teoreettisena viitekehyksenä käytetyn neoklassisen yrityksen teorian mukaan yrittäjä pyrkii maksimoimaan voittonsa tai minimoimaan kustannuksensa tai molempia. Jotta voiton maksimointi tai kustannuksien minimointi onnistuisi, tulee yrittäjän valita optimaalinen tuotannon laajuus. Pitkällä aikavälillä kaikki tuotantopanokset ovat muuttuvia ja niiden käyttömääriä pystytään säätelemään yrittäjän asettamien tavoitteiden mukaisesti. Tällöin on mahdollista saavuttaa suurtuotannon etuja.

Kannattavuuskehitys laajentaneilla tiloilla vastasi Lajusen tutkimustuloksia (2002), joiden mukaan kaikkien tilojen keskimääräinen kannattavuus kohosi hieman laajennuksen myötä, mutta erityisesti ennen laajennusta parhaimmin kannattaneilla tiloilla kannattavuuden paraneminen lähtövuotta paremmaksi vei useita vuosia. Vastaavasti kuin vuoden 2003 kirjanpitotilojen tuloksissa (Ovaska ym. 2004) tässä tutkimuksessa laajentaneilla tiloilla työn tuottavuus oli merkitsevästi suurempi eli työtä tehtiin eläinyksikköä kohden laskettuna vähemmän kuin ei-laajentaneilla tiloilla. Laajentaneilla tiloilla oli käytössä tilastollisesti merkitsevästi enemmän vierasta työpanosta työtunneissa mitattuna, mutta viljelijäperheen oma työmäärä ei eronnut yhtä selkeästi ei-laajentaneisiin tiloihin verrattuna. Monilla tiloilla viljelijäperheen työmäärä on jo niin suuri, ettei sitä ei pystytä enää kasvattamaan laajennuksen yhteydessä.

Viljelijän stressikokemusten ja työssä jaksamisen katsottiin heijastavan viljelijän hyvinvointia ja tyytyväisyyttä työolosuhteisiin. Tutkimuksessa korostui viljelijän oma näkökulma, sillä psykologisen stressinäkemyksen mukaan tilanteen koettu vakavuusaste riippuu sen subjektiivisesta arvioinnista (Cox ym. 1993). Kuten muissakin aihetta käsittelevissä tutkimuksissa (Pråhl-Ollila 1995, Kallio 1997, Leskinen 1999, Uusi-Kämppä ja Rissanen 2004) maidontuottajien keskuudessa esiintyi runsaasti työmääristä ja elinkeinon epävarmuudesta aiheutuvaa stressiä. Tässä tutkimuksessa laajennuksella ei ollut yhteyttä stressin kokemisen yleisyyteen, vaan mitä suurempi tilalla tehty kokonaistyömäärä oli, sitä enemmän stressiä työmäärästä aiheutui.

Johtamistaidot ja stressinsietokyky kuuluvat viljelijän yrittäjäominaisuuksiin, jotka vaihtelevat yksilöllisesti. Saman työmäärän rasittavuus voi vaihdella eri henkilöillä. Toisilla viljelijöillä on luontaisesti hyvät edellytykset selvitä tilan johtamiseen liittyvistä haasteista, ja todennäköisesti nämä henkilöt ovat valmiita ottamaan myös taloudellisia riskejä. Ne viljelijät, jotka laajentavat tilansa tuotantoa, suhtautuvat ei-laajentaneita myönteisemmin tulevaisuuteen. Monet ei-laajentaneiden tilojen viljelijät saattavat harkita jo lopettelevansa maidontuotantoa eivätkä sen vuoksi ole kiinnostuneita kasvattamaan tilakokoaan ja kehittämään tuotantomenetelmiä. Maidontuotanto tuleekin tulevaisuudessa keskittymään 
yhä suurempiin tuotantoyksiköihin (Niemi 2004).

Vaikka tässä tutkimuksessa vieraan työvoiman osuus olikin laajennuksen myötä kasvanut, tilan työmäärä voi pienentyä huomattavasti, jos tiloilla tullaan panostamaan yhä enemmän työtä säästävään ja keventävään uuteen teknologiaan. Tämä voi muuttaa työprosesseja ja maataloustyön luonnetta suuntaan, jossa viljelijän työnkuva ohjautuu käytännön töiden suorittajasta lähemmäs yritysjohtajan toimenkuvaa. Yhä useammat tilan toiminnot ulkoistetaan ja tilojen välinen yhteistyö tulee yleistymään. Moni viljelijä saa työpanokselleen parhaan korvauksen tilan ulkopuolisista töistä. Tutkimuksessa ne viljelijät, jotka kävivät myös tilan ulkopuolisissa ansiotöissä, eivät harjoittaneet yhtä laajaa maataloustuotantoa kuin päätoimiset tilat. Tilan ulkopuoliset työt rajoittivat näillä tiloilla maatalouteen käytettävissä olevaa työaikaa.

\section{Kirjallisuus}

Chatfield, C. \& Collins, A. J. 1980. Introduction to Multivariate Analysis: 212.

Cox, T., Kuk, G. \& Leiter, M. 1993. Burnout, health, workstress and organizational healthiness. Teoksessa Schaufeli, W., Maslach, C. \& Marek, T. Professional Burnout: 180-182.

Kallio, V. 1997. Suomalaisen viljelijäväestön henkinen ilmapiiri. Helsingin yliopisto. Maaseudun tutkimus- ja koulutuskeskuksen julkaisuja 53: 20.

Karttunen, J. \& Klemola, E. 2001. Maatalousyrittäjän fyysisen ja psyykkisen kuormittumisen hallinta laajentavilla kotieläintiloilla. Työterveyttä maatiloille asiakastiedote 2001/1: 2-4.

Kay, R. \& Edwards, W. 1999. Farm management. $4^{\text {th }}$ edition: 158.

Lajunen, A. 2002. Laajentaneiden maitotilojen talous 1996-1999. MTTL:n selvityksiä 2 / 2002: 38.

Leskinen, J. 1999. Maatalouden rakennemuutos ja viljelijän stressi: 2-4.

Niemi, J. 2004. Tulevaisuuden maatilat. Koneviesti 15.10.2004: 41.

Ovaska, S., Sipiläinen, T. \& Ryhänen, M. 2004. Suomen IFCN-maitotilat - Vuoden 2003 tulosten tarkastelu. MTTL:n selvityksiä 74: 14-19.

Pråhl-Ollila, M. 1995. Nuoret viljelijät maatalouden murroksessa. Maatalousyrittäjien eläkelaitoksen julkaisuja 1/95: 82-83.

Ranta, E., Rita, H. \& Kouki, J. 1997. Biometria. Tilastotiedettä ekologeille: 195.

Uusi-Kämppä, J. \& Rissanen, P. (toim.) 2004. Suuret pihatot - eläinten hyvinvointi, lypsyn työnmenekki, työolot ja ympäristönhoito. Maa- ja elintarviketalous 47: 151-152.

Väre, M. 2000. Viljelijöiden tulotasovertailu. MTTL:n tutkimuksia 242: 143. 